\title{
Enhancement of furan aldehydes conversion in Zymomonas mobilis by elevating dehydrogenase activity and cofactor regeneration
}

\author{
Xia Wang, Qiuqiang Gao and Jie Bao*(i)
}

\begin{abstract}
Background: Furfural and 5-hydroxymethylfurfural (HMF) are the two major furan aldehyde inhibitors generated from lignocellulose dilute acid pretreatment which significantly inhibit subsequent microbial cell growth and ethanol fermentation. Zymomonas mobilis is an important strain for cellulosic ethanol fermentation but can be severely inhibited by furfural and (or) HMF. Previous study showed that Z. mobilis contains its native oxidoreductases to catalyze the conversion of furfural and HMF, but the corresponding genes have not been identified.

Results: This study identified a NADPH-dependent alcohol dehydrogenase gene ZMO1771 from Z. mobilis ZM4, which is responsible for the efficient reduction of furfural and HMF. Over-expression of ZMO1771 in Z. mobilis significantly increased the conversion rate to both furfural and HMF and resulted in an accelerated cell growth and improved ethanol productivity in corn stover hydrolysate. Further, the ethanol fermentation performance was enhanced again by co-expression of the transhydrogenase gene $u d h A$ with ZMO1771 by elevating the NADPH availability.
\end{abstract}

Conclusions: A genetically modified Z. mobilis by co-expressing alcohol dehydrogenase gene ZMO1771 with transhydrogenase gene udhA showed enhanced conversion rate of furfural and HMF and accelerated ethanol fermentability from lignocellulosic hydrolysate. The results presented in this study provide an important method on constructing robust strains for efficient ethanol fermentation from lignocellulose feedstock.

Keywords: Zymomonas mobilis, Furfural, 5-Hydroxymethylfurfural (HMF), Reduction, Alcohol dehydrogenase, Transhydrogenase

\section{Background}

Pretreatment is the crucial step to render lignocellulosic biomass to release fermentable sugars, but the harsh pretreatment conditions inevitably lead to the partial overdegradation of lignocellulose components and generate various small molecules with strong inhibition on subsequent microbial fermenting strains [1-3]. Among these inhibitor compounds, the two furan aldehydes, 2-furaldehyde (furfural) and 5-hydroxymethylfurfural (HMF)

\footnotetext{
*Correspondence: jbao@ecust.edu.cn

State Key Laboratory of Bioreactor Engineering, East China University of Science and Technology, 130 Meilong Road, Shanghai 200237, China
}

are the most toxic inhibitors for their strong toxicity to microorganisms and high contents in pretreated lignocellulose biomass $[4,5]$. Fast and complete removal of furfural and HMF from pretreated lignocellulose ("detoxification") by physical, chemical, or biological methods is strongly required to obtain the high conversion yield, titer, and productivity of ethanol product $[1,6,7]$. Ethanologenic strains with both high tolerance to furfural and HMF and high fermentability are an ideal consolidated solution for ethanol production [8].

Conversion of furfural (HMF) into less toxic furfuryl alcohol (HMF alcohol) by multiple NADH- and/ or NADPH-dependent oxidoreductases is the primary 
detoxification pathway in microbial cells to eliminate the inhibition of furan aldehydes [9-11]. In Saccharomyces cerevisiae, over-expression of the oxidoreductase genes $A D H 1, A D H 6$, or ARI1 improved the conversion of furfural or HMF and the ethanol productivity [12-15]. In Escherichia coli, furan aldehydes tolerance was enhanced by silencing of NADPH-dependent oxidoreductases (YqhD and DkgA) and over-expression of NADHdependent FucO $[9,16]$.

Zymomonas mobilis is a natural ethanologenic facultative anaerobic strain and has many desirable industrial characteristics, such as higher specific rate of sugar uptake, high ethanol productivity, high ethanol tolerance, lower biomass production, non-requirement of controlled oxygen addition during fermentation, and regarded as safe status $[17,18]$. Other than the native ethanol production, $Z$. mobilis has been engineered for sorbitol, gluconic acid, levan, 2,3-butanediol, isobutanol, and other chemicals production. Z. mobilis has served as an ideal platform for future biomass biorefinery $[19,20]$, but its weak tolerance to furfural and HMF is the major drawback when applied for ethanol fermentation using lignocellulose feedstock containing furfural and HMF generated from pretreatment $[21,22]$. Several efforts have been tried to improve the inhibitor tolerance in $Z$. mobilis. Inactivation of a global regulator $h f q$ (ZMO0347) decreased the resistance to furfural, HMF, acetate, and vanillin [23]. Mutations to the global transcription sigma factor $\left(\sigma^{70}\right)$ rpoD enhanced the tolerance to furfural stress [24]. Yang et al. confirmed that the tolerance of Z. mobilis to furfural was enhanced by over-expression of the histidine kinase encoding gene ZMO1162, or by disruption of the Sigma 54 modulation protein encoding gene ZMO0038 or 1-deoxy-D-xylulose-5-phosphate synthase encoding genes ZMO1598 and/or ZMO1234. Either knockout of the expression of gene ZMO0282, ZMO0283 or ZMO0285 or down-regulation of the expression of gene ZMO0282, ZMO0283 or ZMO0285 also enhanced the furfural resistance of $Z$. mobilis [25]. Alternatively, the strategy of adaptive laboratory evolution (ALE) was also used for development of a higher furfural-tolerant strain in Z. mobilis, which showed higher tolerance under $3 \mathrm{~g} / \mathrm{L}$ furfural stress condition [26]. These studies offered the methods and gene sources for improving $Z$. mobilis tolerance to furfural and HMF, but further efforts are still needed to meet the requirement of practical lignocellulose biorefining with high inhibitor contents in the pretreated feedstock.

Previous study showed that $Z$. mobilis can reduce furfural or HMF into corresponding furfuryl alcohol or HMF alcohol [22], which suggested that Z. mobilis might also contain the native alcohol dehydrogenases $(\mathrm{ADH})$ or aldo-keto reductases (AKR) to catalyze the reduction of furfural and HMF, but the corresponding genes have not been identified. In present study, the gene ZMO1771 encoding NADPH-dependent alcohol dehydrogenase was confirmed to be responsible for the efficient reduction of furfural and HMF in Z. mobilis ZM4. Over-expression of ZMO1771 in Z. mobilis improved the conversion of furfural and HMF, as well as ethanol fermentability in corn stover hydrolysate. The co-expressing $u d h A$ with ZMO1771 by elevating the conversion of NADH to NADPH further enhanced its conversion capacity of the two furan aldehydes in Z. mobilis. This study provided an important method for the construction of robust ethanologenic strains for efficient ethanol production from lignocellulose feedstock.

\section{Results and discussion}

\section{Reduction evaluation of alcohol dehydrogenase} and aldo-keto reductase gene expression

Z. mobilis ZM4 is able to convert furfural and HMF into less toxic furfuryl alcohol and HMF alcohol by its native alcohol dehydrogenases $(\mathrm{ADH})$ or aldo-keto reductases (AKR) at the low concentration of furfural and HMF [22]. To enhance the reduction capacity and the conversion rate of high level of furfural and HMF, all the available alcohol dehydrogenase genes $(a d h)$ and aldo-keto reductase genes $(a k r)$ were screened from the genome of Z. mobilis ZM4 (GenBank: AE008692.2) as the candidates for over-expression in Z. mobilis. Totally twelve genes were identified, including seven adh genes (ZMO0062, ZMO1236, ZMO1596, ZMO1696, ZMO1722, ZMO1771 and ZMO1993) and five $a k r$ genes (ZMO0976, ZMO1344, ZMO1673, ZMO1773 and ZMO1984). Among these genes, ZMO1236 encoding ADHI and ZMO1596 encoding ADHII on the ethanol synthesis pathway already keep at high transcriptional levels during ethanol fermentation; thus, the two genes (ZMO1236 and ZMO1596) were excluded from the list. Rest of the ten genes were fused with the reporter gene gfp into pHW20a (Additional file 1: Figure S1) to yield ten $Z$. mobilis recombinants. The obtained recombinants harboring the expression cassette were confirmed by both fluorescence detection at $488 \mathrm{~nm}$ and enzyme activity assay (Table 1 ), and then cultured in RM medium containing $2 \mathrm{~g} / \mathrm{L}$ of furfural or $4 \mathrm{~g} / \mathrm{L}$ of HMF (Table 2).

The results indicated that the expression of ZMO1771, ZMO1696, and ZMO1722 enhanced the furfural and HMF conversion, in which the expression of ZMO1771 encoding an iron-dependent alcohol dehydrogenase showed the most significant enhancement. $1.51 \mathrm{~g} / \mathrm{L}$ of furfural or $1.89 \mathrm{~g} / \mathrm{L}$ of HMF was converted at the mid-log phase of the fermentation after ZMO1771 was over-expressed, leading to the increase of furfural conversion by $33.63 \%$ and of HMF conversion by 
Table 1 Gene expression detection by fluorescence and enzyme assay of cell-free extract in recombinant strains

\begin{tabular}{|c|c|c|c|c|c|}
\hline & Fluorescent detection $^{a}$ & Activity (mU/mg cru & protein) & & \\
\hline & & Furfural + NADPH & $\mathrm{HMF}+\mathrm{NADPH}$ & Furfural + NADH & $\mathrm{HMF}+\mathrm{NADH}$ \\
\hline ZM4(pHW20a-gfp) (Control) & + & $21.15 \pm 0.81$ & $11.12 \pm 0.45$ & $110.87 \pm 3.82$ & $100.83 \pm 2.73$ \\
\hline ZM4(pHW20a-ZMO0062) & + & $24.53 \pm 0.99$ & $14.82 \pm 0.05$ & $175.22 \pm 9.91$ & $135.51 \pm 6.61$ \\
\hline ZM4(pHW20a-ZMO1696) & + & $29.40 \pm 0.85$ & $13.62 \pm 0.25$ & $134.00 \pm 2.83$ & $105.14 \pm 1.62$ \\
\hline ZM4(pHW20a-ZMO1722) & + & $23.87 \pm 0.87$ & $12.24 \pm 0.00$ & $104.51 \pm 2.69$ & $99.40 \pm 6.91$ \\
\hline ZM4(pHW20a-ZMO1771) & + & $32.31 \pm 1.46$ & $18.22 \pm 0.45$ & $102.97 \pm 2.65$ & $100.85 \pm 3.89$ \\
\hline ZM4(pHW20a-ZMO1993) & + & $22.16 \pm 0.00$ & $11.62 \pm 0.00$ & $115.46 \pm 0.00$ & $101.64 \pm 4.96$ \\
\hline ZM4(pHW20a-ZMO0976) & + & $62.24 \pm 7.65$ & $15.97 \pm 0.38$ & $133.27 \pm 6.70$ & $110.50 \pm 3.19$ \\
\hline ZM4(pHW20a-ZMO1344) & + & $21.64 \pm 0.00$ & $12.34 \pm 0.45$ & $108.83 \pm 2.80$ & $94.19 \pm 4.76$ \\
\hline ZM4(pHW20a-ZMO1673) & + & $22.31 \pm 0.50$ & $13.25 \pm 0.30$ & $116.88 \pm 5.01$ & $106.93 \pm 2.39$ \\
\hline ZM4(pHW20a-ZMO1773) & + & $21.66 \pm 0.49$ & $11.89 \pm 0.29$ & $134.06 \pm 4.86$ & $107.71 \pm 3.24$ \\
\hline ZM4(pHW20a-ZMO1984) & + & $20.46 \pm 0.83$ & $11.37 \pm 0.46$ & $99.31 \pm 0.00$ & $86.39 \pm 2.84$ \\
\hline
\end{tabular}

Standard deviations were derived from at least two independent determinations

a + : fluorescence can be detected under fluorescence microscope; -: no fluorescence under fluorescence microscope

Table 2 Cell growth, glucose consumption, ethanol formation, and furan aldehydes conversion of recombinant Z. mobilis strains

\begin{tabular}{|c|c|c|c|c|c|}
\hline Inhibitors & Recombinant strains & Cell growth $\left(\mathrm{OD}_{600}\right)$ & $\begin{array}{l}\text { Glucose consumption } \\
\text { (g/L) }\end{array}$ & $\begin{array}{l}\text { Ethanol production } \\
\text { (g/L) }\end{array}$ & $\begin{array}{l}\text { Inhibitor con- } \\
\text { version (g/L) }\end{array}$ \\
\hline \multirow[t]{11}{*}{ Furfural } & ZM4(pHW20a-gfp) (Control) & $0.361 \pm 0.003$ & $4.81 \pm 0.58$ & $1.37 \pm 0.02$ & $1.13 \pm 0.09$ \\
\hline & ZM4(pHW20a-ZMO0062) & $0.387 \pm 0.003$ & $4.13 \pm 0.26$ & $1.36 \pm 0.04$ & $1.04 \pm 0.03$ \\
\hline & ZM4(pHW20a-ZMO1696) & $0.404 \pm 0.000$ & $4.28 \pm 0.19$ & $1.39 \pm 0.02$ & $1.18 \pm 0.03$ \\
\hline & ZM4(pHW20a-ZMO1722) & $0.393 \pm 0.004$ & $4.78 \pm 0.22$ & $1.56 \pm 0.06$ & $1.34 \pm 0.06$ \\
\hline & ZM4(pHW20a-ZMO1771) & $0.378 \pm 0.027$ & $4.60 \pm 0.26$ & $1.49 \pm 0.00$ & $1.51 \pm 0.02$ \\
\hline & ZM4(pHW20a-ZMO1993) & $0.359 \pm 0.009$ & $4.87 \pm 0.03$ & $1.44 \pm 0.00$ & $1.02 \pm 0.02$ \\
\hline & ZM4(pHW20a-ZMO0976) & $0.362 \pm 0.007$ & $4.09 \pm 0.05$ & $1.37 \pm 0.06$ & $0.99 \pm 0.05$ \\
\hline & ZM4(pHW20a-ZMO1344) & $0.380 \pm 0.002$ & $4.56 \pm 0.04$ & $1.58 \pm 0.03$ & $1.01 \pm 0.03$ \\
\hline & ZM4(pHW20a-ZMO1673) & $0.314 \pm 0.008$ & $3.71 \pm 0.01$ & $1.09 \pm 0.20$ & $0.93 \pm 0.03$ \\
\hline & ZM4(pHW20a-ZMO1773) & $0.293 \pm 0.002$ & $3.19 \pm 0.24$ & $1.17 \pm 0.14$ & $0.93 \pm 0.16$ \\
\hline & ZM4(pHW20a-ZMO1984) & $0.348 \pm 0.009$ & $4.80 \pm 0.09$ & $1.39 \pm 0.09$ & $1.00 \pm 0.02$ \\
\hline \multirow[t]{11}{*}{ HMF } & ZM4(pHW20a-gfp) (Control) & $0.419 \pm 0.005$ & $6.47 \pm 0.04$ & $2.26 \pm 0.14$ & $1.40 \pm 0.09$ \\
\hline & ZM4(pHW20a-ZMO0062) & $0.439 \pm 0.009$ & $5.57 \pm 0.25$ & $2.12 \pm 0.17$ & $1.43 \pm 0.02$ \\
\hline & ZM4(pHW20a-ZMO1696) & $0.497 \pm 0.014$ & $6.48 \pm 0.07$ & $2.04 \pm 0.13$ & $1.67 \pm 0.08$ \\
\hline & ZM4(pHW20a-ZMO1722) & $0.427 \pm 0.021$ & $6.02 \pm 0.04$ & $1.89 \pm 0.05$ & $1.85 \pm 0.03$ \\
\hline & ZM4(pHW20a-ZMO1771) & $0.471 \pm 0.001$ & $5.96 \pm 0.24$ & $2.41 \pm 0.01$ & $1.89 \pm 0.04$ \\
\hline & ZM4(pHW20a-ZMO1993) & $0.419 \pm 0.001$ & $5.92 \pm 0.42$ & $2.16 \pm 0.08$ & $1.19 \pm 0.08$ \\
\hline & ZM4(pHW20a-ZMO0976) & $0.466 \pm 0.005$ & $6.95 \pm 0.04$ & $2.38 \pm 0.05$ & $1.41 \pm 0.05$ \\
\hline & ZM4(pHW20a-ZMO1344) & $0.396 \pm 0.020$ & $5.96 \pm 0.94$ & $2.18 \pm 0.04$ & $1.65 \pm 0.21$ \\
\hline & ZM4(pHW20a-ZMO1673) & $0.356 \pm 0.013$ & $5.44 \pm 0.10$ & $2.01 \pm 0.04$ & $1.16 \pm 0.01$ \\
\hline & ZM4(pHW20a-ZMO1773) & $0.306 \pm 0.009$ & $5.27 \pm 0.45$ & $1.78 \pm 0.04$ & $1.03 \pm 0.00$ \\
\hline & ZM4(pHW20a-ZMO1984) & $0.400 \pm 0.002$ & $5.20 \pm 0.05$ & $2.23 \pm 0.03$ & $1.55 \pm 0.07$ \\
\hline
\end{tabular}

In RM medium containing $2 \mathrm{~g} / \mathrm{L}$ of furfural or $4 \mathrm{~g} / \mathrm{L}$ of $\mathrm{HMF}$ at $30^{\circ} \mathrm{C}$. ZM4(pHW20a-gfp) is the control strain only expressing the reporter gene $\mathrm{gfp}$. The fermentation performance was detected at the mid-log phase, where $12 \mathrm{~h}$ for furfural and $16 \mathrm{~h}$ for HMF. Standard deviations were derived from at least two independent determinations

$35.00 \%$, comparing to the control without ZMO1771 over-expression (Table 2). However, the cell growth, glucose consumption, and ethanol production of the three recombinants above did not show significant improvement in the synthetic medium with furfural or HMF addition. The rest of the seven genes, including two $a d h$ genes (ZMO0062 and ZMO1993) and five $a k r$ genes (ZMO0976, ZMO1344, ZMO1673, ZMO1773, 
and ZMO1984), did not show significant enhancement on furfural and HMF conversion. The in vitro enzymatic analysis in previous study [27] as well as in present study (Table 1) showed ZMO0976 encoding xylose reductase possessed NADPH-dependent furfural and HMF reduction activity, but no enhancement was observed in $Z$. mobilis ZM4 by expressing ZMO0976. The phenomenon suggests that the in vitro capacity of an enzyme may not go to the in vivo performance in Z. mobilis.

Then the inhibitors conversion of all the ten recombinants was further evaluated in corn stover hydrolysate containing $56.74 \mathrm{~g} / \mathrm{L}$ of glucose, $24.80 \mathrm{~g} / \mathrm{L}$ of xylose, $0.62 \mathrm{~g} / \mathrm{L}$ of furfural, $0.34 \mathrm{~g} / \mathrm{L}$ of HMF, $2.85 \mathrm{~g} / \mathrm{L}$ acetic acid as well as 4-hydromethylbenzoaldehyde, vanillin, syringaldehyde, and other inhibitors. The results again showed that the expression of ZMO1771 significantly increased furfural and HMF conversion rate (Table 3; Fig. 1): furfural by $0.26 \mathrm{~g} / \mathrm{L}$ at $12 \mathrm{~h}$ and $0.40 \mathrm{~g} / \mathrm{L}$ at $24 \mathrm{~h}$, HMF by $0.03 \mathrm{~g} / \mathrm{L}$ at $12 \mathrm{~h}$, and $0.07 \mathrm{~g} / \mathrm{L}$ at $24 \mathrm{~h}$, respectively, while other gene expression did not show the obvious effect. The significantly difference between the corn stover hydrolysate and synthetic medium is that the cell growth, glucose consumption, and ethanol production increased by $35.00,78.79,100 \%$ at $36 \mathrm{~h}$, and $33.33,74.14,100 \%$ at

Table 3 Furfural and HMF conversion rate of recombinant Z. mobilis strains in corn stover hydrolysate

\begin{tabular}{|c|c|c|c|c|}
\hline \multirow[t]{2}{*}{$\begin{array}{l}\text { Recombinant } \\
\text { strains }\end{array}$} & \multicolumn{2}{|c|}{$\begin{array}{l}\text { Furfural conversion } \\
\text { (g/L) }\end{array}$} & \multicolumn{2}{|c|}{ HMF conversion (g/L) } \\
\hline & $12 \mathrm{~h}$ & $24 \mathrm{~h}$ & $2 \mathrm{~h}$ & $24 \mathrm{~h}$ \\
\hline $\begin{array}{l}\text { ZM4(pHW20a-gfp) } \\
\text { (Control) }\end{array}$ & & & 01 & 0 \\
\hline $\begin{array}{l}\text { ZM4(pHW20a- } \\
\text { ZMO0062) }\end{array}$ & 1 & $28 \pm 0.02$ & $0.01 \pm$ & $0.01 \pm 0.00$ \\
\hline $\begin{array}{l}\text { ZM4(pHW20a- } \\
\text { ZMO1696) }\end{array}$ & & & & $0.05 \pm 0.03$ \\
\hline $\begin{array}{l}\text { ZM4(pHW20a- } \\
\text { ZMO1722) }\end{array}$ & 4 & $32 \pm 0.05$ & $0.02 \pm 0.01$ & $0.05 \pm 0.01$ \\
\hline $\begin{array}{r}\text { ZM4(pHV } \\
\text { ZMO17 }\end{array}$ & $26 \pm 0.02$ & $.40 \pm 0.01$ & $0.03 \pm 0.01$ & $0.07 \pm 0.00$ \\
\hline $\begin{array}{r}\mathrm{ZM} 4(\mathrm{ph} \\
\mathrm{ZMO}\end{array}$ & $6 \pm 0.00$ & $33 \pm 0.01$ & $0.01 \pm 0.01$ & $0.03 \pm 0.00$ \\
\hline $\begin{array}{l}\text { ZM4(pHW20a- } \\
\text { ZMO0976) }\end{array}$ & $17 \pm 0.02$ & $0.31 \pm 0.00$ & $0.01 \pm 0.00$ & $0.03 \pm 0.02$ \\
\hline $\begin{array}{l}\text { ZM4(pHW20a- } \\
\text { ZMO1344) }\end{array}$ & $4 \pm 0.01$ & $27 \pm 0.01$ & $0.01 \pm 0.00$ & $0.03 \pm 0.01$ \\
\hline $\begin{array}{l}\text { ZM4(pHW20a- } \\
\text { ZMO1673) }\end{array}$ & $.18 \pm 0.00$ & $0.29 \pm 0.03$ & $0.01 \pm 0.00$ & $0.06 \pm 0.00$ \\
\hline $\begin{array}{l}\text { ZM4(pHW20a- } \\
\text { ZMO1773) }\end{array}$ & $.13 \pm 0.00$ & $0.23 \pm 0.01$ & $0.02 \pm 0.01$ & $0.02 \pm 0.01$ \\
\hline $\begin{array}{l}\text { ZM4(pHW20a- } \\
\text { ZMO1984) }\end{array}$ & $0.20 \pm 0.02$ & $0.31 \pm 0.04$ & $0.02 \pm 0.00$ & $0.04 \pm 0.02$ \\
\hline
\end{tabular}

The corn stover hydrolysate contained $59.45 \mathrm{~g} / \mathrm{L}$ of glucose, $24.03 \mathrm{~g} / \mathrm{L}$ of xylose, $3.21 \mathrm{~g} / \mathrm{L}$ of acetic acid, $0.38 \mathrm{~g} / \mathrm{L}$ of HMF and $0.69 \mathrm{~g} / \mathrm{L}$ of furfural at $30^{\circ} \mathrm{C}$. Standard deviations were derived from at least two independent determinations

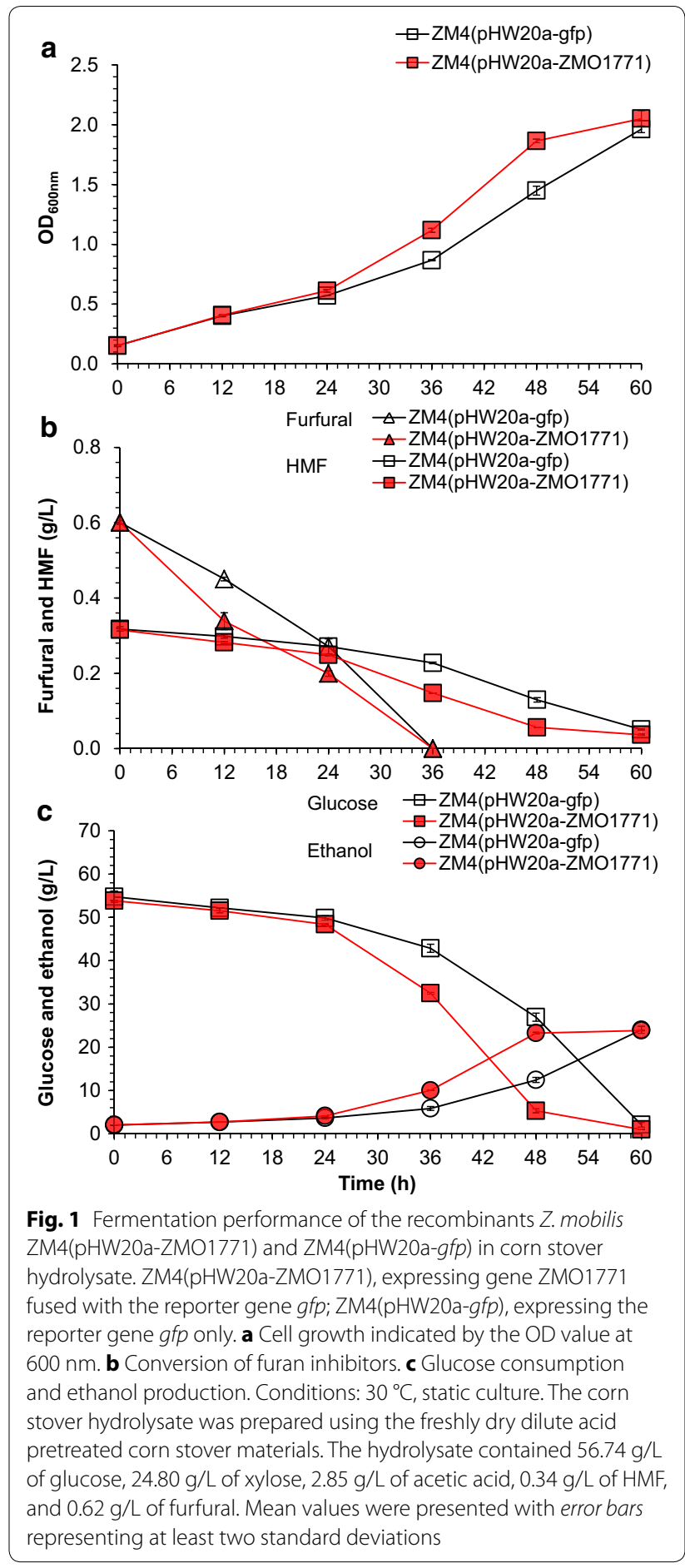

$48 \mathrm{~h}$, respectively (Fig. 1). The results suggest that the expression of ZMO1771 significantly increased the furfural and HMF conversion as well as ethanol productivity in the high inhibitors containing corn stover hydrolysate.

Compared with the results in simple-defined RM medium, the improved conversion of furfural and HMF 
by expression of ZMO1771 may effectively alleviate the synergistic inhibition of furan aldehydes with other inhibitors in the hydrolysate, which then activate cell growth and ethanol production. Besides, the complicated hydrolysate components, such as the mineral element contents and other rich nutrients may also play a positive role to facilitate the reduction of furan aldehydes by ZMO1771, just as the previous studies on S. cerevisiae showed that enriched media, including complex media or high glucose concentrations, influence the inhibitor tolerance of cells $[28,29]$. Thus, we recommend the use of a lignocellulosic hydrolysate for final fermentation evaluation of recombinant strains.

\section{Cofactor preference of ZMO1771 and reduction modification on furfural and HMF}

The reductase enzymes for furan aldehydes conversion were either NADH or NADPH dependent, and the regeneration of the NADH or NADPH cofactor is an important factor for furan aldehydes conversion. The enzyme activity assay showed that furan aldehydes reductase activity of Z. mobilis ZM4(pHW20a-ZMO1771) increased by $52.8 \%$ on furfural and $63.8 \%$ on HMF when NADPH was used as the cofactor, while the activity was almost same to the control when NADH was used (Table 1). The cofactor preference of NADPH was further proved using the purified protein from the expression of ZMO1771 in E. coli BL21: the reductase activity was $3.632 \mathrm{U} / \mathrm{mg}$ protein on furfural substrate and $1.999 \mathrm{U} / \mathrm{mg}$ protein on HMF substrate when NADPH was used as the cofactor, while no reductase activity was detected when NADH was used. These results confirm that the ZMO1771 encoding enzyme is NADPH dependent for furfural and HMF reduction, rather than NADH.

Preference of NADPH by the relevant reductase enzymes on the furfural and HMF conversion pathway may negatively interfere with the NADPH/NADP ${ }^{+}$ balance of $Z$. mobilis and then weaken its tolerance to furfural and HMF. Additional NADPH supply may further enhance the furfural and HMF conversion of $Z$. mobilis when ZMO1771 is over-expressed. Two transhydrogenase genes pntAB and $u d h A$ from $E$. coli involved in NADPH generation were selected and coexpressed with ZMO1771 to facilitate the availability of $\mathrm{NADPH}$. The two genes encode the only two transhydrogenases documented in living organisms responsible for the interconversion between NADH and NADPH $\left(\mathrm{NADH}+\mathrm{NADP}^{+} \leftrightarrow \mathrm{NAD}^{+}+\mathrm{NADPH}\right)$ [30]. Each gene was inserted into pHW20a together with ZMO1771, but in reversed direction under the regulation of Pgap promoter (Additional file 1: Figure S1). The PntAB and UdhA activities in the co-expression and the single expression of pntAB or $u d h A$ were essentially the same $(0.037 \mathrm{U} / \mathrm{mg}$ protein for PntAB in both expressions, and 0.002 and $0.003 \mathrm{U} / \mathrm{mg}$ protein for UdhA activity, respectively), implying that each gene was expressed successfully in $Z$. mobilis.

The constructed recombinants were firstly evaluated in RM medium containing $2 \mathrm{~g} / \mathrm{L}$ of furfural or $4 \mathrm{~g} / \mathrm{L}$ of HMF (Table 4). $1.57 \mathrm{~g} / \mathrm{L}$ of furfural or $2.72 \mathrm{~g} / \mathrm{L}$ of HMF was converted by the co-expression of the transhydrogenase gene $u d h A$ with ZMO1771, leading to the increase of furfural conversion by $19.85 \%$ and of HMF conversion by $38.07 \%$, respectively, over the cell with the expression of ZMO1771 only. The cell growth, glucose consumption, and ethanol production were improved significantly as well by $31.65,21.93$, and $35.68 \%$ under the tolerance to HMF, but only slight changes to furfural. However, the over-expression of the second transhydrogenase gene $p n t A B$ did not result in a significant change on furfural or HMF conversion in Z. mobilis (Table 4). The results suggest that $u d h A$ not pntAB favors the direction of $\mathrm{NADPH}$ production in the overexpression of ZMO1771 in $Z$. mobili where more NADPH might be required for

Table 4 Cell growth, glucose consumption, ethanol formation, and furan aldehydes conversion of co-expression recombinant strains

\begin{tabular}{|c|c|c|c|c|c|}
\hline Inhibitors & Recombinant strains & Cell growth $\left(\mathrm{OD}_{600}\right)$ & $\begin{array}{l}\text { Glucose consumption } \\
\text { (g/L) }\end{array}$ & $\begin{array}{l}\text { Ethanol } \\
\text { production }(g / L)\end{array}$ & $\begin{array}{l}\text { Inhibitor conversion } \\
\text { (g/L) }\end{array}$ \\
\hline \multirow[t]{4}{*}{ Furfural } & ZM4(pHW20a-ZMO1771) & $0.259 \pm 0.002$ & $3.84 \pm 0.11$ & $1.14 \pm 0.03$ & $1.31 \pm 0.25$ \\
\hline & ZM4(pHW20a-ZMO1771-pntAB) & $0.252 \pm 0.011$ & $3.44 \pm 0.09$ & $1.04 \pm 0.02$ & $1.49 \pm 0.03$ \\
\hline & ZM4(pHW20a-ZMO1771-udhA) & $0.243 \pm 0.006$ & $4.02 \pm 0.59$ & $0.91 \pm 0.05$ & $1.57 \pm 0.27$ \\
\hline & ZM4(pHW20a-ZMO1771-ZMO0367) & $0.230 \pm 0.005$ & $3.52 \pm 0.34$ & $1.14 \pm 0.07$ & $1.42 \pm 0.11$ \\
\hline \multirow[t]{4}{*}{ HMF } & ZM4(pHW20a-ZMO1771) & $0.357 \pm 0.004$ & $6.43 \pm 0.76$ & $1.99 \pm 0.08$ & $1.97 \pm 0.18$ \\
\hline & ZM4(pHW20a-ZMO1771-pntAB) & $0.421 \pm 0.025$ & $6.50 \pm 0.13$ & $2.28 \pm 0.15$ & $2.23 \pm 0.14$ \\
\hline & ZM4(pHW20a-ZMO1771-udhA) & $0.470 \pm 0.036$ & $7.84 \pm 0.63$ & $2.70 \pm 0.08$ & $2.72 \pm 0.05$ \\
\hline & ZM4(pHW20a-ZMO1771-ZMO0367) & $0.391 \pm 0.009$ & $5.66 \pm 0.25$ & $2.18 \pm 0.16$ & $2.02 \pm 0.01$ \\
\hline
\end{tabular}

In RM medium containing $2 \mathrm{~g} / \mathrm{L}$ of furfural or $4 \mathrm{~g} / \mathrm{L}$ of HMF at $30^{\circ} \mathrm{C}$. The fermentation performance was detected at the mid-log phase, where $12 \mathrm{~h}$ for furfural and $16 \mathrm{~h}$ for HMF. Standard deviations were derived from at least two independent determinations 
furfural or HMF reduction, a similar function of $u d h A$ has been reported previously $[31,32]$.

The co-expression of the gene ZMO0367 encoding glucose-6-phosphate dehydrogenase (G6PDH) with ZMO1771 in Z. mobilis was also evaluated. The G6PDH activity of the co-expression of ZMO0367 was considerably high (3.011 U/mg protein), but the co-expression of ZMO0367 with ZMO1771 did not show any enhancement on furfural and HMF conversion in RM medium comparing to the single expression of ZMO1771 (Table 4).

\section{Fermentation evaluation of the co-expression recombinants in corn stover hydrolysate}

The co-expression recombinant of $u d h A$ with ZMO1771 in Z. mobilis was grown in the corn stover hydrolysate containing $59.45 \mathrm{~g} / \mathrm{L}$ of glucose, $24.03 \mathrm{~g} / \mathrm{L}$ of xylose, $3.21 \mathrm{~g} / \mathrm{L}$ of acetic acid, $0.69 \mathrm{~g} / \mathrm{L}$ of furfural, and $0.38 \mathrm{~g} / \mathrm{L}$ of $\mathrm{HMF}$ as well as other inhibitors (Fig. 2). The co-expression exhibited the maximum conversion capacity, approximately $50 \%$ of the initial furfural was reduced at $12 \mathrm{~h}$ and completely reduced at $24 \mathrm{~h}, 12 \mathrm{~h}$ shorter than the time used for complete conversion of furfural by the recombinant with the ZMO1771 expression only. The new recombinant also completely converted HMF within $48 \mathrm{~h}$, comparing with $12 \%$ of the residual HMF left even after 60 h's culture by the recombinant with ZMO1771 expression only. The cell growth, glucose consumption, and ethanol production were also accelerated by $55.56,60.00$, and $46.67 \%$ at $36 \mathrm{~h}$, respectively; at $48 \mathrm{~h}$, the accelerations were 10.00 , 12.12 , and $25.00 \%$, respectively. The maximum cell growth and ethanol titer of the co-expression recombinant were approximately equal to the control at $60 \mathrm{~h}$.

The Ethanol fermentation performance in corn stover hydrolysate revealed that the co-expression of $u d h A$ with ZMO1771 promoted the furfural and HMF reduction rate by elevating the NADPH availability by delivering the proton from NADH which was not the cofactor of ZMO1771 for furfural or HMF conversion reaction. This regeneration of NADPH from NADH by UdhA, however, could compete for NADH with the biosynthesis of ethanol from acetaldehyde by ADHI or ADHII and inhibit the ethanol formation rate when furfural or HMF conversion reactions proceed. Figure 2c showed this tendency of slow ethanol formation by $Z$. mobilis during the period of furfural and HMF conversion. When furfural was completely converted and most of HMF was converted, the recombinant $Z$. mobilis of the co-expression of ZMO1771 with $u d h A$ started its faster rate of ethanol generation than the wild $Z$. mobilis strain in which furfural and HMF existed at relatively high levels. The fermentation results of the co-expression of ZMO1771 with $u d h A$ suggest that cofactor manipulation was an effective tool for increasing the conversion of furan aldehyde inhibitors in $Z$. mobilis.

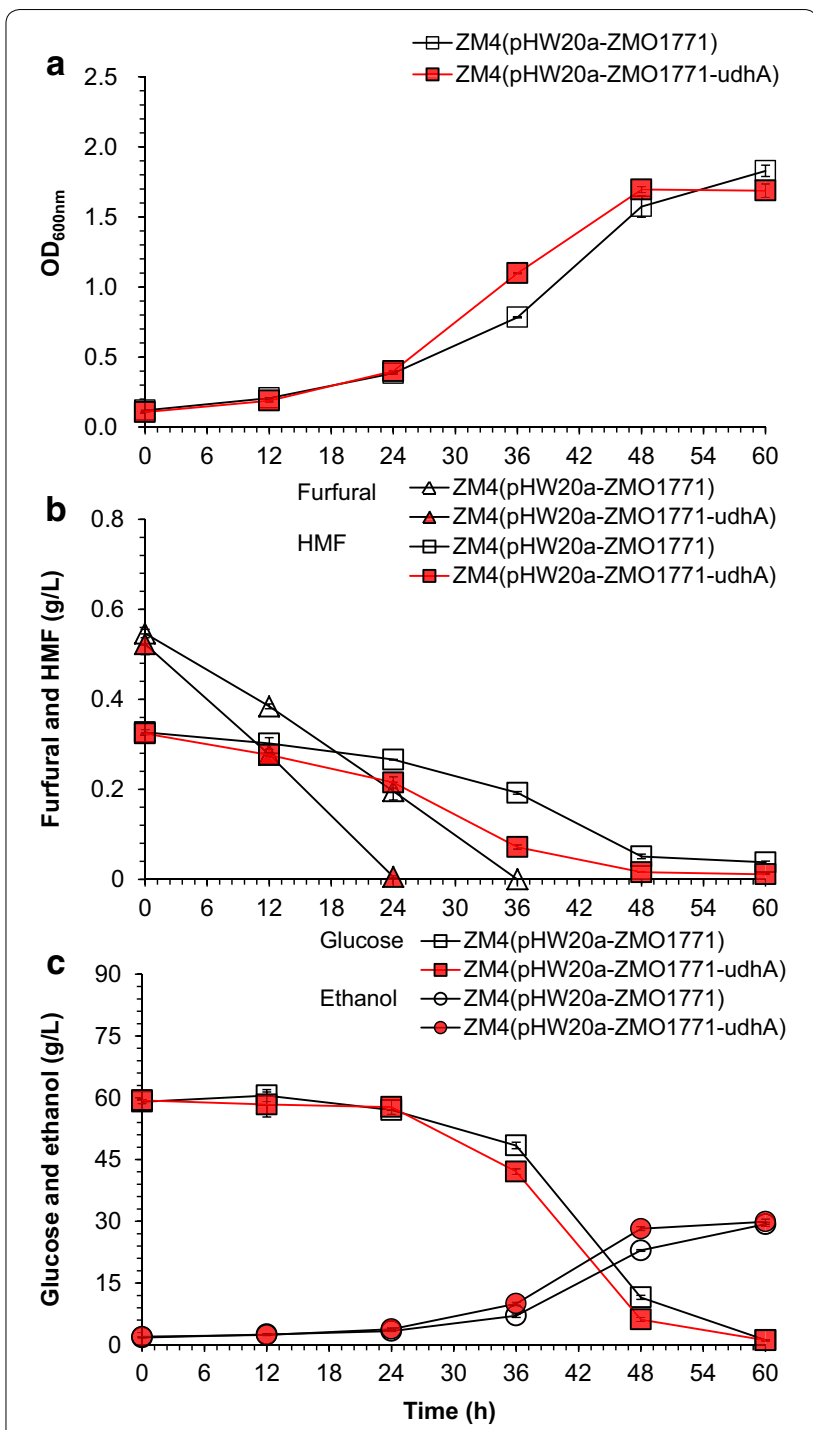

Fig. 2 Fermentation performance of the recombinants $Z$. mobilis ZM4(pHW20a-ZMO1771-udhA) and ZM4(pHW20a-ZMO1771) in corn stover hydrolysate. ZM4(pHW20a-ZMO1771-udhA), co-expressing gene udhA with ZMO1771; ZM4(pHW20a-ZMO1771), expressing gene ZMO1771 only. a Cell growth indicated by the OD value at $600 \mathrm{~nm}$. b Conversion of furan inhibitors. c Glucose consumption and ethanol production. Conditions: $30^{\circ} \mathrm{C}$, static culture. The corn stover hydrolysate was prepared using the freshly dry dilute acid pretreated corn stover materials. The hydrolysate contained $59.45 \mathrm{~g} / \mathrm{L}$ of glucose, $24.03 \mathrm{~g} / \mathrm{L}$ of xylose, $3.21 \mathrm{~g} / \mathrm{L}$ of acetic acid, $0.38 \mathrm{~g} / \mathrm{L}$ of $\mathrm{HMF}$ and $0.69 \mathrm{~g} / \mathrm{L}$ of furfural. Mean values were presented with error bars representing at least two standard deviations

\section{Conclusions}

The work in this study confirmed alcohol dehydrogenase ZMO1771 of Z. mobilis ZM4 possessed NADPHdependent furfural and HMF reductase activity, which has never been reported before. Expression of ZMO1771 in Z. mobilis ZM4 significantly enhanced furfural and 
HMF conversion resulting in faster cell growth, glucose consumption, and ethanol production. In addition, the co-expression of another transhydrogenase gene $u d h A$ with ZMO1771 further increased its fermentation performance in hydrolysate by elevation of dehydrogenase activity and cofactor NADPH availability. Previous transcriptome study response to furfural revealed that the inhibitor tolerance of $Z$. mobilis involved multiple responses of cell membrane biogenesis, respiratory chain, DNA replication, DNA recombination and repair, transcriptional regulation, and some universal stress response [21]. The present work of identification of relevant oxidoreductase genes for furfural and HMF conversion is just a beginning. More genes involved in the tolerance to furan aldehyde inhibitors in Z. mobilis ZM4 should be identified, and then a higher tolerance strain could be developed by the combination of ZMO1771 with the new identified tolerance genes in the future. However, the robust strain with high furan aldehydes degradation constructed in this study would facilitate the efficient ethanol production from lignocellulose feedstock.

\section{Methods}

\section{Strains, media, and culture conditions}

The details of the strains and plasmids used in this study are given in Additional file 2: Table S1. Z. mobilis ZM4 (ATCC31821) and its recombinant strains were cultured at $30{ }^{\circ} \mathrm{C}$ without shaking in the rich medium (RM) containing $20 \mathrm{~g} / \mathrm{L}$ of glucose, $2 \mathrm{~g} / \mathrm{L}$ of $\mathrm{KH}_{2} \mathrm{PO}_{4}, 10 \mathrm{~g} / \mathrm{L}$ of yeast extract. $20 \mu \mathrm{g} / \mathrm{mL}$ of tetracycline was added to the RM medium where the recombinant strains were cultured. Pre-culture was prepared by inoculating one fresh colony in $5 \mathrm{~mL}$ of RM medium in $15 \mathrm{~mL}$ test tube and cultivated for $20 \mathrm{~h}$ to the stationary phase. All the culture was transferred into $50 \mathrm{~mL}$ of fresh $\mathrm{RM}$ in $250 \mathrm{~mL}$ flask and incubated overnight as the seed culture. $10 \%$ inoculum of the sub-culture was then adopted for all fermentation experiments.

E. coli strains were grown with Luria-Bertani (LB) medium at $37{ }^{\circ} \mathrm{C} .50 \mu \mathrm{g} / \mathrm{mL}$ of kanamycin or $20 \mu \mathrm{g} / \mathrm{mL}$ of tetracycline was added to the medium accordingly. The shuttle vector pHW20a [33] was used for construction of $Z$. mobilis recombinants, and vector pET-28a(+) was used for expressing alcohol dehydrogenase ZMO1771 in E. coli BL21.

\section{Corn stover hydrolysate preparation}

Corn stover was harvested from Dancheng, Henan, China in 2012. Cellulase enzyme Youtell\#6 was purchased from Hunan Youtell Biochemical Co., Yueyang, Hunan, China. The filter paper activity, the cellobiase activity, and the protein concentration were $145 \mathrm{FPU} / \mathrm{g}$, $344 \mathrm{IU} / \mathrm{g}, 90 \mathrm{mg} / \mathrm{g}$ enzyme, respectively [34].
Dry dilute acid pretreatment was used for corn stover pretreatment [35, 36]. Briefly, $2.5 \mathrm{~g}$ of sulfuric acid per $100 \mathrm{~g}$ of dry corn stover was co-currently fed into a $20 \mathrm{~L}$ pretreatment reactor with the ratio of the solid (the dry materials) to the liquid (the sulfuric acid solution) at 2:1 $(\mathrm{w} / \mathrm{w})$. The pretreatment was operated at $175^{\circ} \mathrm{C}$ for $5 \mathrm{~min}$ under helically agitation at $50 \mathrm{rpm}$.

Corn stover hydrolysate was prepared in a $5 \mathrm{~L}$ bioreactor equipped with helical ribbon impeller for mixing. Freshly pretreated corn stover was hydrolyzed using cellulase at dosage of $15 \mathrm{FPU} / \mathrm{g}$ corn stover matter at $50^{\circ} \mathrm{C}, \mathrm{pH}$ 4.8 for $48 \mathrm{~h}$. The slurry was centrifuged at $10,000 \mathrm{rpm}$ for $10 \mathrm{~min}$, and then the hydrolysate was autoclaved at $115^{\circ} \mathrm{C}$ for $20 \mathrm{~min}$ and filtered by filter paper before use. No nutrients were added to the hydrolysate for all fermentation.

\section{DNA preparation, manipulation, and transformation}

The genomic DNA of Z. mobilis ZM4 and E. coli $\mathrm{K}-12$ were extracted using TIANamp Bacterial DNA Kit (Tiangen Biotech, Beijing, China). The oligonucleotides used for DNA amplification are listed in Additional file 3: Table S2. The constructed recombinant plasmids are given in Additional file 1: Figure S1. Each target oxidoreductase gene was amplified and fused with a reporter gene $g f p$ via a short linker encoding seven glycines. The expression cassette was then inserted into vector pHW20a under the regulation of the Peno promoter. The constructed plasmid was introduced into Z. mobilis ZM4 using E. coli S17-1 $\lambda \pi$ by biparental transconjugation [33].

ZMO1771 was also inserted in pET-28a $(+)$ and expressed in E. coli BL21 for in vitro enzyme activity assay. The plasmid contained in frame $\mathrm{N}$-terminal (His) ${ }_{6}^{-}$ tag before the start codon of the gene.

\section{Fermentation analysis of recombinant $Z$. mobilis strains}

$Z$. mobilis recombinants were cultured both in $50 \mathrm{~mL}$ of RM medium or the freshly pretreated corn stover hydrolysate (without detoxification to remove the inhibitors contained) in $250 \mathrm{~mL}$ flasks by inoculating of $10 \%$ of seed culture as described above. $50 \%$ of the lethal furfural $(2 \mathrm{~g} / \mathrm{L})$ or HMF $(4 \mathrm{~g} / \mathrm{L})$ concentrations to the $Z$. mobilis cells were selected as the initial inhibitor concentrations in the RM medium before the fermentation started. Cell growth was determined periodically by measuring the optical density at $600 \mathrm{~nm}\left(\mathrm{OD}_{600}\right)$ using DU800 spectrophotometer (Beckman Coulter Inc., USA). The samples were withdrawn periodically and centrifuged at $12,000 \mathrm{rpm}$ for $5 \mathrm{~min}$ and filtered through $0.22 \mu \mathrm{m}$ filters. Glucose, ethanol, furfural, and HMF were analyzed using HPLC (LC-20 AD, refractive index detector RID-10A, Shimadzu, Kyoto, Japan) with an Aminex HPX-87H column (Bio-rad, Hercules, CA, USA) at $65{ }^{\circ} \mathrm{C}$ at the flow rate of $0.6 \mathrm{~mL} / \mathrm{min}$ using $5 \mathrm{mM} \mathrm{H}_{2} \mathrm{SO}_{4}$ as the mobile phase. 


\section{Protein purification and enzyme activity assays}

Cells were collected at the exponential phase, and then the crude enzyme solution was prepared as described previously [37]. The his-tagged alcohol dehydrogenase encoded by ZMO1771 was induced by $0.1 \mathrm{mM}$ IPTG and purified at $4{ }^{\circ} \mathrm{C}$ with $\mathrm{Ni}$ Aogarose 6FF resin (Aogma, Shanghai, China). Protein concentration was determined by Bradford protein assay using BSA as the calibration standard.

Furfural and HMF reduction activity was measured by monitoring the decrease in absorbance at $340 \mathrm{~nm}$ caused by $\mathrm{NAD}(\mathrm{P}) \mathrm{H}$ conversion at $30{ }^{\circ} \mathrm{C}$ [38]. One unit $(\mathrm{U})$ was defined as the amount of enzyme converting $1 \mu \mathrm{mol}$ of $\mathrm{NAD}(\mathrm{P}) \mathrm{H}$ per minute. Reaction mixture was performed in $100 \mathrm{mM}$ phosphate buffer $(\mathrm{pH}$ 7.0) containing $100 \mu \mathrm{M} N A D(P) H, 10 \mathrm{mM}$ furfural or HMF. Glucose-6-phosphate dehydrogenase (G6PDH) and transhydrogenase (UdhA and PntAB) activity was determined at $30{ }^{\circ} \mathrm{C}$ by measuring the increase in absorbance at $340 \mathrm{~nm}$ and $375 \mathrm{~nm}$, respectively. Reaction mixture for G6PDH contained $100 \mathrm{mM}$ Tris- $\mathrm{HCl}$ (pH 7.5), $200 \mathrm{mM} \mathrm{KCl}, 10 \mathrm{mM} \mathrm{MgCl}, 1 \mathrm{mM} \mathrm{NAD(P),}$ $2 \mathrm{mM}$ glucose-6-phosphate [39]. Reaction mixture for UdhA and PntAB included $50 \mathrm{mM}$ Tris- $\mathrm{HCl}$ (pH 7.6), $2 \mathrm{mM} \mathrm{MgCl}, 0.5 \mathrm{mM} \mathrm{NADPH}, 0.5 \mathrm{mM} 3$-acetylpyridine adenine dinucleotide [30].

\section{Additional files}

Additional file 1: Figure S1. Plasmids harboring functional genes used in this study. a pHW20a-gfp, the control plasmid. b plasmids harboring adh or akr genes. c plasmids harboring genes involved in NADPH generation.

Additional file 2: Table S1. Microbial strains and plasmids used in this study.

Additional file 3: Table S2. Oligonucleotide primers used in this study. The underlined letters indicated the restriction sites.

\begin{abstract}
Abbreviations
HMF: 5-hydroxymethylfurfural; HMF alcohol: 5-hydroxymethylfurfuryl alcohol; ADH: alcohol dehydrogenase; AKR: aldo-keto reductase; ARI: aldehyde reductase; ALDH: aldehyde dehydrogenase; G6PDH: glucose-6-phosphate dehydrogenase; ALE: adaptive laboratory evolution; IPTG: isopropyl $\beta$-D-1thiogalactopyranoside; NADH: nicotinamide adenine dinucleotide (reduced); NADPH: nicotinamide adenine dinucleotide phosphate (reduced); NAD: nicotinamide-adenine dinucleotide; NADP: nicotinamide adenine dinucleotide phosphate.
\end{abstract}

\section{Authors' contributions}

XW and JB designed the experiment; JB conceived the study: XW conducted the experiment; QQG analyzed the methods and commented the manuscript critically; XW and JB wrote the manuscript. All authors read and approved the manuscript.

\section{Acknowledgements}

Special thanks are addressed to Dr. Yi Xia for her advice and assistance on genetic manipulation experiments and to Dr. Hongsen Zhang for his assistance on corn stover hydrolysate preparation.

\section{Competing interests}

The authors declare that they have no competing interests.

\section{Availability of supporting data}

All data generated or analyzed during this study are included in this article and its supplementary information files.

\section{Funding}

This research was supported by the National High-Tech Program of China (2012AA022301) and the Natural Science Foundation of China (31300070).

Received: 12 October 2016 Accepted: 18 January 2017

Published online: 31 January 2017

\section{References}

1. Jönsson LJ, Alriksson B, Nilvebrant NO. Bioconversion of lignocellulose: inhibitors and detoxification. Biotechnol Biofuels. 2013;6(1):16.

2. Larsson S, Palmqvist E, Hahn-Hagerdal B, Tengborg C, Stenberg K, Zacchi G, Nilvebrant NO. The generation of fermentation inhibitors during dilute acid hydrolysis of softwood. Enzyme Microb Technol. 1999;24(3-4):151-9.

3. Klinke HB, Thomsen AB, Ahring BK. Inhibition of ethanol-producing yeast and bacteria by degradation products produced during pre-treatment of biomass. Appl Microbiol Biotechnol. 2004;66(1):10-26.

4. Wierckx N, Koopman F, Ruijssenaars HJ, Winde JH. Microbial degradation of furanic compounds: biochemistry, genetics, and impact. Appl Microbiol Biotechnol. 2011;92(6):1095-105.

5. Heer D, Sauer U. Identification of furfural as a key toxin in lignocellulosic hydrolysates and evolution of a tolerant yeast strain. Microb Biotechnol. 2008:1(6):497-506.

6. Chandel AK, Kapoor RK, Singh A, Kuhad RC. Detoxification of sugarcane bagasse hydrolysate improves ethanol production by Candida shehatae NCIM 3501. Bioresour Technol. 2007;98(10):1947-50.

7. Mussatto SI, Roberto IC. Alternatives for detoxification of diluted-acid lignocellulosic hydrolyzates for use in fermentative processes: a review. Bioresour Technol. 2004;93(1):1-10.

8. Taylor MP, Mulako I, Tuffin M, Cowan D. Understanding physiological responses to pre-treatment inhibitors in ethanologenic fermentations. Biotechnol J. 2012;7(9):1169-81.

9. Miller EN, Jarboe LR, Yomano LP, York SW, Shanmugam KT, Ingram LO. Silencing of NADPH-dependent oxidoreductase genes ( $y q h D$ and $d k g A$ ) in furfural-resistant ethanologenic Escherichia coli. Appl Environ Microbiol. 2009;75(13):4315-23.

10. Almeida JRM, Röder A, Modig T, Laadan B, Lidén G, Gorwa-Grauslund M-F. $\mathrm{NADH}$ - vs NADPH-coupled reduction of 5-hydroxymethyl furfural (HMF) and its implications on product distribution in Saccharomyces cerevisiae. Appl Microbiol Biotechnol. 2008;78(6):939-45.

11. Liu ZL, Moon J, Andersh BJ, Slininger PJ, Weber S. Multiple gene-mediated $\mathrm{NAD}(\mathrm{P}) \mathrm{H}$-dependent aldehyde reduction is a mechanism of in situ detoxification of furfural and 5-hydroxymethylfurfural by Saccharomyces cerevisiae. Appl Microbiol Biotechnol. 2008;81(4):743-53.

12. Petersson A, Almeida JRM, Modig T, Karhumaa K, Hahn-Hägerdal B, Gorwa-Grauslund MF, Lidén G. A 5-hydroxymethyl furfural reducing enzyme encoded by the Saccharomyces cerevisiae ADH6 gene conveys HMF tolerance. Yeast. 2006;23(6):455-64.

13. Hasunuma T, Ismail KS, Nambu Y, Kondo A. Co-expression of TAL1 and $A D H 1$ in recombinant xylose-fermenting Saccharomyces cerevisiae improves ethanol production from lignocellulosic hydrolysates in the presence of furfural. J Biosci Bioeng. 2014;117(2):165-9.

14. Ishii J, Yoshimura K, Hasunuma T, Kondo A. Reduction of furan derivatives by overexpressing NADH-dependent Adh1 improves ethanol fermentation using xylose as sole carbon source with Saccharomyces cerevisiae harboring XR-XDH pathway. Appl Microbiol Biotechnol. 2012;97(6):2597-607.

15. Liu ZL, Moon J. A novel NADPH-dependent aldehyde reductase gene from Saccharomyces cerevisiae NRRL Y-12632 involved in the detoxification of aldehyde inhibitors derived from lignocellulosic biomass conversion. Gene. 2009;446(1):1-10. 
16. Wang X, Miller EN, Yomano LP, Zhang X, Shanmugam KT, Ingram LO. Increased furfural tolerance due to overexpression of $\mathrm{NADH}$-dependent oxidoreductase FucO in Escherichia coli strains engineered for the production of ethanol and lactate. Appl Environ Microbiol. 2011;77(15):5132-40.

17. Zhang M, Eddy C. Metabolic engineering of a pentose metabolism pathway in ethanologenic Zymomonas mobilis. Science. 1995;267(5195):240.

18. Humbird D, Davis R, Tao L, Kinchin C, Hsu D, Aden A, Schoen P, Lukas J, Olthof B, Worley M, Sexton D, Dudgeon D. Process design and economics for biochemical conversion of lignocellulosic biomass to ethanol: diluteacid pretreatment and enzymatic hydrolysis of corn stover. NREL technical report NREL/TP-5100-47764, National Renewable Energy Laboratory, Golden, CO. 2011

19. He MX, Wu B, Qin H, Ruan ZY, Tan FR, Wang JL, Shui ZX, Dai LC, Zhu QL, Pan K, Tang XY, Wang WG, Hu QC. Zymomonas mobilis: a novel platform for future biorefineries. Biotechnol Biofuels. 2014;7:101.

20. Yang S, Fei Q, Zhang Y, Contreras LM, Utturkar SM, Brown SD, Himmel ME, Zhang M. Zymomonas mobilis as a model system for production of biofuels and biochemicals. Microb Biotechnol. 2016;9(6):699-717.

21. He MX, Wu B, Shui ZX, Hu QC, Wang WG, Tan FR, Tang XY, Zhu QL, Pan K, Li Q, Su XH. Transcriptome profiling of Zymomonas mobilis under furfural stress. Appl Microbiol Biotechnol. 2012;95(1):189-99.

22. Franden MA, Pilath HM, Mohagheghi A, Pienkos PT, Zhang M. Inhibition of growth of Zymomonas mobilis by model compounds found in lignocellulosic hydrolysates. Biotechnol Biofuels. 2013;6(1):99.

23. Yang S, Pelletier DA, Lu T-YS, Brown SD. The Zymomonas mobilis regulator hfa contributes to tolerance against multiple lignocellulosic pretreatment inhibitors. BMC Microbiol. 2010;10(1):135.

24. Tan FR, Dai LC, Wu B, Qin H, Shui ZX, Wang JL, Zhu QL, Hu QC, Ruan $Z Y$, He MX. Improving furfural tolerance of Zymomonas mobilis by rewiring a sigma factor RpoD protein. Appl Microbiol Biotechnol. 2015:99(12):5363-71.

25. Yang S, Linger J, Franden MA, Pienkos PT, Zhang M. Biocatalysts with enhanced inhibitor tolerance. In: USPTO. Biocatalysts with enhanced inhibitor tolerance. US9206445. 2015.

26. Shui ZX, Qin H, Wu B, Ruan ZY, Wang LS, Tan FR, Wang JL, Tang XY, Dai LC, Hu GQ, He MX. Adaptive laboratory evolution of ethanologenic Zymomonas mobilis strain tolerant to furfural and acetic acid inhibitors. Appl Microbiol Biotechnol. 2015:99(13):5739-48.

27. Agrawal M, Chen RR. Discovery and characterization of a xylose reductase from Zymomonas mobilis ZM4. Biotechnol Lett. 2011;33(11):2127-33.

28. Taherzadeh MJ, Gustafsson L, Niklasson C, Liden G. Physiological effects of 5-hydroxymethylfurfural on Saccharomyces cerevisiae. Appl Microbiol Biotechnol. 2000;53(6):701-8.
29. Liu ZL, Slininger PJ, Dien BS, Berhow MA, Kurtzman CP, Gorsich SW. Adaptive response of yeasts to furfural and 5-hydroxymethylfurfural and new chemical evidence for HMF conversion to 2,5-bis-hydroxymethylfuran. J Ind Microbiol Biotechnol. 2004;31(8):345-52.

30. Sauer U, Canonaco F, Heri S, Perrenoud A, Fischer E. The soluble and membrane-bound transhydrogenases UdhA and PntAB have divergent functions in NADPH metabolism of Escherichia coli. J Biol Chem. 2004;279(8):6613-9.

31. Jan J, Martinez I, Wang Y, Bennett GN, San KY. Metabolic engineering and transhydrogenase effects on NADPH availability in Escherichia coli. Biotechnol Prog. 2013:29(5):1124-30.

32. Sanchez AM, Andrews J, Hussein I, Bennett GN, San KY. Effect of overexpression of a soluble pyridine nucleotide transhydrogenase (UdhA) on the production of poly(3-hydroxybutyrate) in Escherichia coli. Biotechnol Progr. 2006;22(2):420-5.

33. Dong HW, Bao J, Ryu DDY, Zhong JJ. Design and construction of improved new vectors for Zymomonas mobilis recombinants. Biotechnol Bioeng. 2011;108(7):1616-27.

34. Zhang HS, Zhang J, Bao J. High titer gluconic acid fermentation by Aspergillus niger from dry dilute acid pretreated corn stover without detoxification. Bioresour Technol. 2016;203:211-9.

35. He YQ, Zhang J, Bao J. Dry dilute acid pretreatment by co-currently feeding of corn stover feedstock and dilute acid solution without impregnation. Bioresour Technol. 2014;158:360-4.

36. Zhang J, Wang X, Chu D, He Y, Bao J. Dry pretreatment of lignocellulose with extremely low steam and water usage for bioethanol production. Bioresour Technol. 2011;102(6):4480-8.

37. Dong HW, Fan LQ, Luo Z, Zhong JJ, Ryu DD, Bao J. Improvement of ethanol productivity and energy efficiency by degradation of inhibitors using recombinant Zymomonas mobilis (pHW20a-fdh). Biotechnol Bioeng. 2013;110(9):2395-404.

38. Almeida JRM, Modig T, Röder A, Lidén G, Gorwa-Grauslund M-F. Pichia stipitis xylose reductase helps detoxifying lignocellulosic hydrolysate by reducing 5-hydroxymethyl-furfural (HMF). Biotechnol Biofuels. 2008:1(1):12.

39. Qi H, Li S, Zhao S, Huang D, Xia M, Wen J. Model-driven redox pathway manipulation for improved isobutanol production in Bacillus subtilis complemented with experimental validation and metabolic profiling analysis. PLoS ONE. 2014;9(4):e93815.

\section{Submit your next manuscript to BioMed Central and we will help you at every step:}

- We accept pre-submission inquiries

- Our selector tool helps you to find the most relevant journal

- We provide round the clock customer support

- Convenient online submission

- Thorough peer review

- Inclusion in PubMed and all major indexing services

- Maximum visibility for your research

Submit your manuscript at www.biomedcentral com/submit 